\title{
Flow cytometric observation of picophytoplankton community structure in the cascade reservoirs along the Wujiang River, SW China
}

\author{
Baoli WANG, Cong-Qiang LIU, Fushun $\mathrm{WANG}^{1)}$, Yuanxiu YU and Yanyou WU \\ State Key Laboratory of Environmental Geochemistry, Institute of Geochemistry, Chinese Academy of Sciences, Guiyang 550002, \\ P.R. China \\ ${ }^{1)}$ Institute of Applied Radiation, School of Environmental and Chemical Engineering, Shanghai University, Shanghai 201800, P.R. \\ China \\ *e-mail corresponding author: baoliwang@163.com
}

\begin{abstract}
Picophytoplankton community structure has been seasonally investigated in the cascade reservoirs along the Wujiang River from April 2006 to January 2007. Besides picoeukaryotes, two groups of picocyanobacteria have also been detected by flow cytometry. One is a phycoerythrin-rich picocyanobacteria (PE-rich Pcy), the other is a red-fluorescing cells with lacking orange fluorescence and could be a phycocyanin-rich picocyanobacteria (PC-rich Pcy). The average abundances of PC-rich Pcy, PE-rich Pcy and picoeukaryotes were $10^{3}, 10^{4}$ and $10^{2}$ cells $\mathrm{mL}^{-1}$, respectively. PE-rich Pcy was the dominant population but showed a reduction with eutrophication, and therefore the community structure of picophytoplankton transformed from dominant PE-rich Pcy to dominant PE-rich Pcy and PC-rich Pcy, which suggested they are excellent indicators for the change of trophic state. Picophytoplankton community structure also presented a seasonal variation, indicating the different response of each picophytoplankton group to water temperature.
\end{abstract}

Key words: phycoerythrin-rich picocyanobacteria, phycocyanin-rich picocyanobacteria, picoeukaryotes

\section{INTRODUCTION}

Picophytoplankton (0.2-2 $\mu \mathrm{m}$; Sieburth et al. 1978) comprise prokaryotic picocyanobacteria and eukaryotic phototrophs. They are ubiquitous in both freshwater and marine ecosystem (Stockner 1988; Callieri 2007). Picocyanobacteria use phycobilisome as accessory pigments for photosynthetic light collection (Glazer 1982). According to phycobilisome composition, freshwater picocyanobacteria are divided into phycoerythrin (PE)rich and phycocyanin (PC)-rich types (Pick 1991; Becker et al. 2002). Nowadays, it is well known that picophytoplankton abundance and biomass increase and its relative importance decreases with the increase of trophic state in freshwater systems (SzelagWasielewska 1997; Stockner et al. 2000; Bell \& Kalff 2001; Callieri \& Stockner 2002). Light and water temperature are also two important factors controlling picophytoplankton growth (Wehr 1993; Agawin et al. 2000; Wakabayashi \& Ichise 2004).

Rivers are the chief carriers of dissolved and particulate matter from land to sea (e.g., Meybeck 1982; Ittekkot 1988). Damming on river alters its hydrological condition, material cycle and then transforms aquatic ecosystem from riverine type to limnological type (e.g., Humborg et al. 1997). Reservoirs created by dams are complex and dynamic ecosystems and it is important to understand how these ecosystems operate and respond to change for an efficient management (Wetzel 2001). Picophytoplankton is an important component in fresh- water ecosystem (Callieri \& Stockner 2002). They respond swiftly to environmental conditions and can be effectively used as early indicators of ecosystem change (e.g., Schallenberg \& Burns 2001). Nowadays, few studies have conducted with picophytoplankton in the cascade reservoirs (e.g., Becker et al. 2002).

The Wujiang River is a major power source for China's massive West-to-East Power Transmission Project. A series of reservoirs have been constructed for this project since 1971 . We have seasonally investigated three groups of picophytoplankton (PC-rich Pcy, PErich Pcy, and picoeukaryotes) in these reservoirs. The aim of this study is to understand the succession of different picophytoplankton groups in these cascade reservoirs, and to discern the indicative function of picophytoplankton on environmental change.

\section{METHODS}

\subsection{Study sites and sampling}

The 1037-km-long Wujiang River is a southern tributary of the Changiiang River, and it has a runoff of 53.4 billion cubic meters with a fall of $2124 \mathrm{~m}$. The river water chemistry is controlled by carbonate dissolution by both carbonic and sulfuric acid, and dominated by $\mathrm{Ca}^{2+}, \mathrm{HCO}_{3}^{-}, \mathrm{Mg}^{2+}$ and $\mathrm{SO}_{4}{ }^{2-}$ (Han \& Liu 2004).

Investigations were carried out at five reservoirs along the Wujiang River (Fig. 1). They are Wujiangdu Reservoir, Dongfeng Reservoir, Hongjiadu Reservoir, Yinzidu Reservoir, Puding Reservoir (Tab. 1). A total of 25 stations were investigated (Fig. 1.). At the fol- 


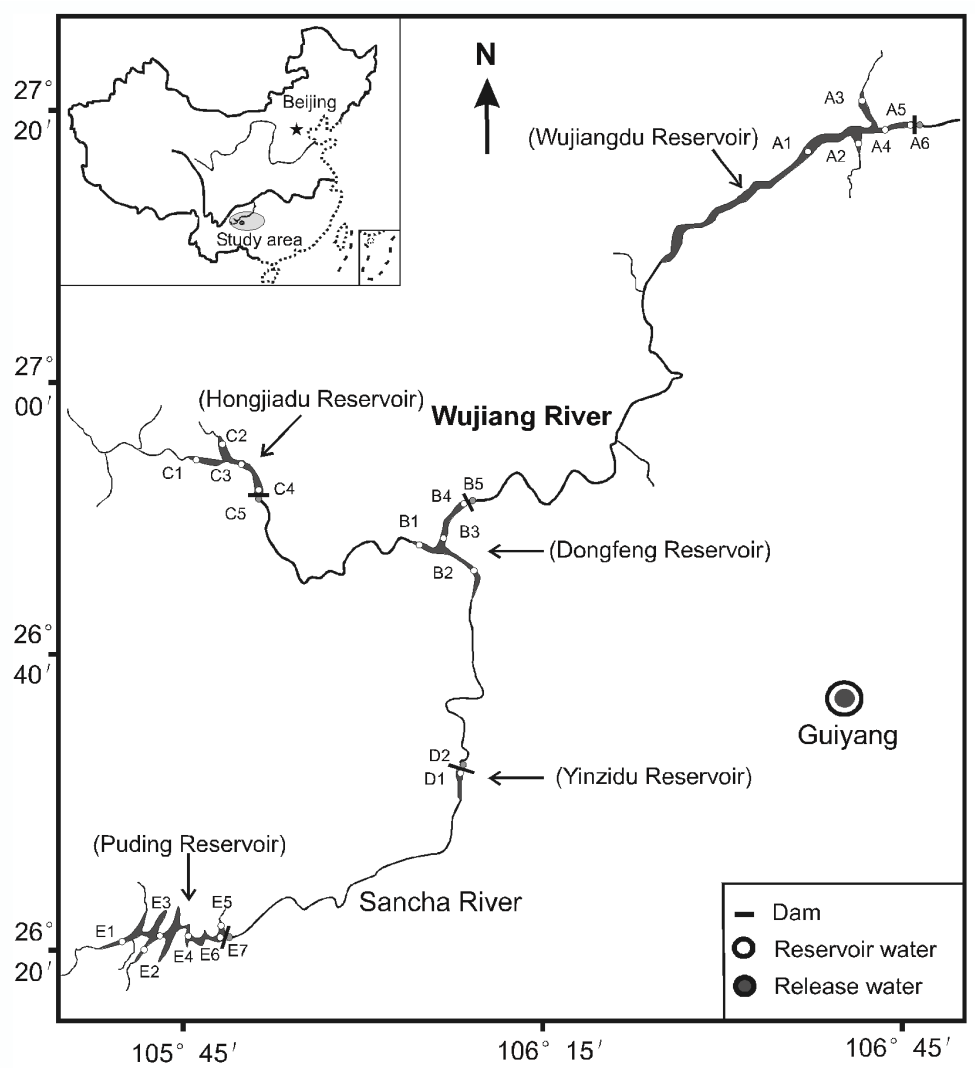

Fig. 1. Map showing sampling locations and sample numbers.

Tab. 1. Hydrographic parameters of the investigated reservoirs.

\begin{tabular}{lccccc}
\hline Reservoir & $\begin{array}{c}\text { Storage level } \\
(\mathrm{m})\end{array}$ & $\begin{array}{c}\text { Reservoir capacity } \\
\left(10^{8} \mathrm{~m}^{3}\right)\end{array}$ & $\begin{array}{c}\text { Backwater length } \\
(\mathrm{km})\end{array}$ & $\begin{array}{c}\text { Water head } \\
(\mathrm{m})\end{array}$ & $\begin{array}{c}\text { Impounded time } \\
(\mathrm{y})\end{array}$ \\
\hline Wujiangdu & 760 & 21.40 & 82.94 & 113 & 1971 \\
Dongfeng & 970 & 8.63 & 43.65 & 116 & 1989 \\
Hongjiadu & 1140 & 30.98 & 86.00 & 115 & 2001 \\
Yinzidu & 1088 & 5.43 & 8.94 & 93.3 & 2001 \\
Puding & 1145 & 3.77 & 7.51 & 46.4 & 1989 \\
\hline
\end{tabular}

lowing stations, water samples were taken with $5 \mathrm{~L}$ Niskin bottles at different depths: A1, A4, and D1 at the depths of $0,10,20,40,60 \mathrm{~m}, \mathrm{~A} 5$ at the depths of 0,10 , $20,40,60$, and $80 \mathrm{~m}, \mathrm{~B} 3$ at the depths of $0,20,40,60$ $\mathrm{m}, \mathrm{B} 4$ and C4 at the depths of $0,20,40,60,80 \mathrm{~m}, \mathrm{E} 4$ at the depths of $0,5,10,20 \mathrm{~m}$, E6 at the depths of $0,5,10$, $20,30 \mathrm{~m}$, respectively. Release water samples were collected at stations A6, B5, C5, D2, and E7 and other water samples were obtained from surface water.

Sample collection was carried out in April, July, October, 2006 and January, 2007. Water samples for determining abundances of different picophytoplankton groups were filtered by $50 \mu \mathrm{m}$ fabrics in order to remove the bigger impurities and were put aside in darkness for $15 \mathrm{~min}$ with paraformaldehyde; then immediately stored in liquid nitrogen till analysis in one month (Pan et al. 2005). Water temperature was measured in situ by a portable multi-parameter instrument (pIONneer 65). In autumn, immediately after collec- tion, water samples were filtered through $0.22 \mu \mathrm{m}$ membrane filters (Millipore) and cold stored in darkness for measuring the concentrations of $\mathrm{PO}_{4}{ }^{3-}, \mathrm{NO}_{3}{ }^{-}$by automatic flow analyzer (Sans plus Systems, SKALAR). A small portion of each sample was stored for measuring total nitrogen and phosphorus (TN and TP), respectively. TP was determined spectrophotometrically (Unico UV-2000) using the molybdenum blue method after alkaline potassium persulfate digestion. TN was also analyzed spectrophotometrically (Unico UV-2000) after alkaline potassium persulfate digestion.

\subsection{Analysis of picophytoplankton}

Picophytoplankton samples were analyzed on a FACScan flow cytometer (Becton Dickinson, San Jose, CA, USA) equipped with an air-cooled argon laser (488 $\mathrm{nm}, 15 \mathrm{~mW})$. Forward light scatter, side light scatter, orange fluorescence $(585 \pm 21 \mathrm{~nm})$ and red fluorescence $(>650 \mathrm{~nm})$ were recorded for each particle in the sam- 


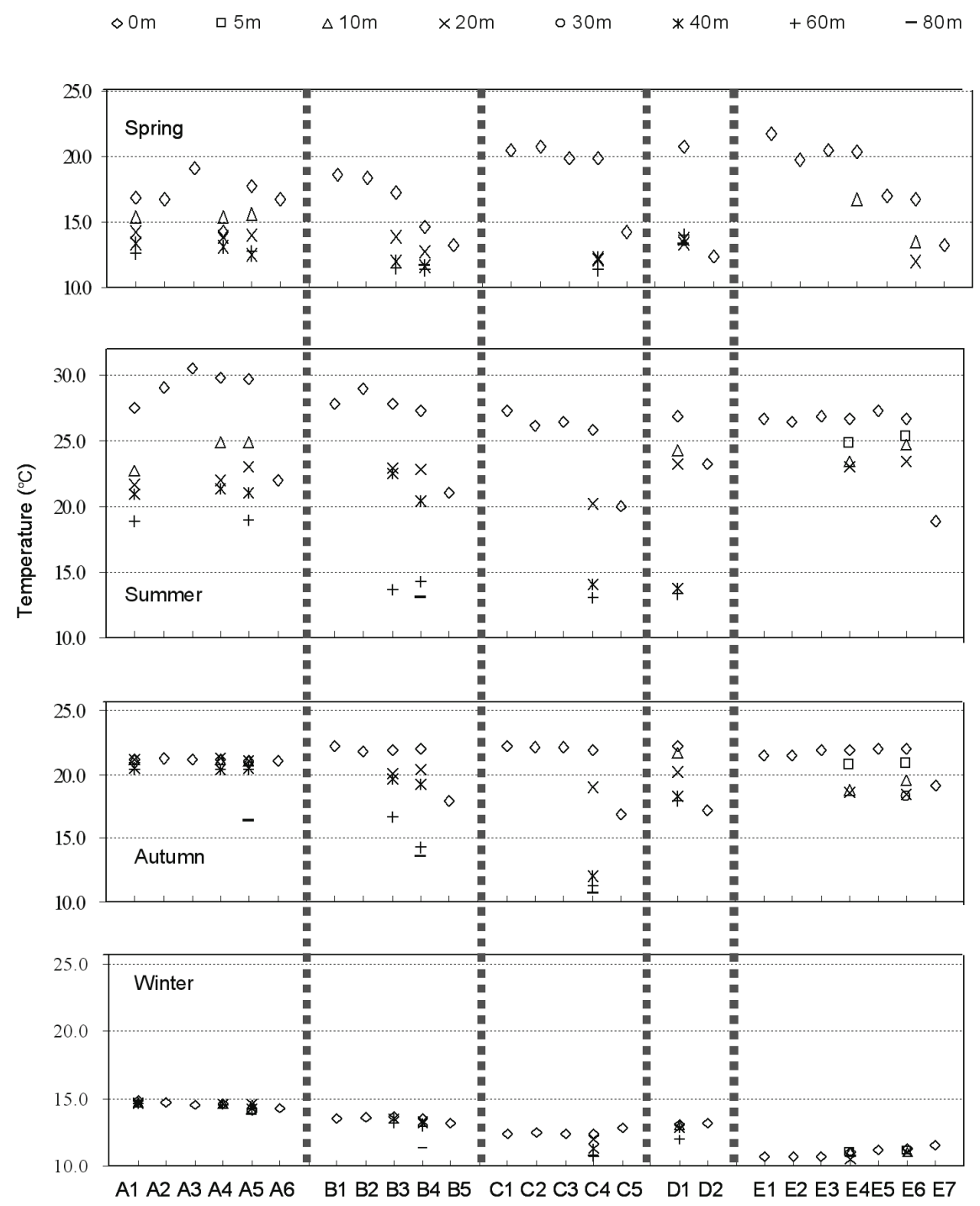

Fig. 2. Profile of temperature in the investigated reservoirs.

ple, and the data obtained were processed with CELLQuest $^{\mathrm{TM}}$ software (Becton Dickinson, San Jose, CA, USA). Yellowish green fluorescent beads $(1.002 \mu \mathrm{m})$ (Polysciences Inc., catalogue \# 18660) were added to calibrate cell fluorescence emissions and light scatter signals. The picophytoplankton groups could be discriminated and enumerated according to their specific autofluorescence properties and light scatter differences (Collier 2000).

Statistical analysis of the data was done with the software SPSS (version 11.5; SPSS Inc.). Pearson's correlation coefficient analysis was carried out.

\section{RESULTS}

\subsection{Hydrographic conditions}

Thermal stratification developed during spring and summer; water temperature began to mix at the end of autumn and mixed well during winter in the investigated reservoirs (Fig. 2). The average surface water temperatures were $17.7^{\circ} \mathrm{C}$ in April, $26.2^{\circ} \mathrm{C}$ in July, $20.9{ }^{\circ} \mathrm{C}$ in October, and $12.8^{\circ} \mathrm{C}$ in January, respectively. There was clear vertical decrease in temperature with depth during spring and summer (e.g., 13.0-25.9 ${ }^{\circ} \mathrm{C}$ at station $\mathrm{C} 4$ in July), which was more pronounced in the larger reservoirs (i.e., in Wujiangdu Reservoir and Hongjiadu Reservoir; Tab. 1). The water column of Wujiangdu Reservoir was not thermally stratified at the depth above 60 meters (i.e., 20.4-21.2 ${ }^{\circ} \mathrm{C}$ ). However, the thermal stratification in water column of other four reservoirs was still clear (e.g., 10.6-21.9 ${ }^{\circ} \mathrm{C}$ at station C4) in October. In January Puding Reservoir showed lower water temperature than other four reservoirs, probably due to its smallest reservoir capacity and highest storage level (Tab. 1). Release water came from the deep water of the reservoir. In those reservoirs in which thermal stratification was developed the temperatures of release water showed values lower than those of surface water. 
Tab. 2. Average concentration and $\mathrm{SD}$ of nutrients $\left(\mu \mathrm{mol} \mathrm{L} \mathrm{L}^{-1}\right)$ in the reservoirs in autumn. In square bracket: Min - Max concentration.

\begin{tabular}{l|cccc}
\hline \multirow{2}{*}{ Wujiangdu } & $\mathrm{NO}_{3}{ }^{-}$ & $\mathrm{PO}_{4}{ }^{3-}$ & $\mathrm{TN}$ & $\mathrm{TP}$ \\
\hline \multirow{3}{*}{ Dongfeng } & $228.07 \pm 61.00$ & $8.19 \pm 11.55$ & $470.43 \pm 91.47$ & $9.08 \pm 11.74$ \\
& {$[50.18-385.81]$} & {$[0.04-44.40]$} & {$[317.77-617.47]$} & {$[1.50-48.98]$} \\
Hongjiadu & $215.11 \pm 18.57$ & $0.04 \pm 0.02$ & $372.57 \pm 96.15$ & $0.99 \pm 0.67$ \\
& {$[198.15-254.38]$} & {$[0.01-0.09]$} & {$[291.68-629.00]$} & {$[0.23-2.64]$} \\
\multirow{3}{*}{ Yinzidu } & $259.16 \pm 27.03$ & $0.05 \pm 0.04$ & $498.96 \pm 153.49$ & $1.00 \pm 1.15$ \\
\multirow{3}{*}{ Puding } & {$[218.17-310.43]$} & {$[0.02-0.12]$} & {$[346.28-843.16]$} & {$[0.10-3.53]$} \\
& $185.47 \pm 68.80$ & $0.04 \pm 0.03$ & $302.70 \pm 39.85$ & $1.65 \pm 0.94$ \\
& {$[65.70-254.39]$} & {$[0.02-0.10]$} & {$[243.14-363.27]$} & {$[0.10-2.64]$} \\
& $192.84 \pm 25.92$ & $0.03 \pm 0.01$ & $413.10 \pm 110.91$ & $0.70 \pm 0.39$ \\
& {$[157.18-255.59]$} & {$[0.02-0.06]$} & {$[248.60-712.72]$} & {$[0.23-1.50]$} \\
\hline
\end{tabular}
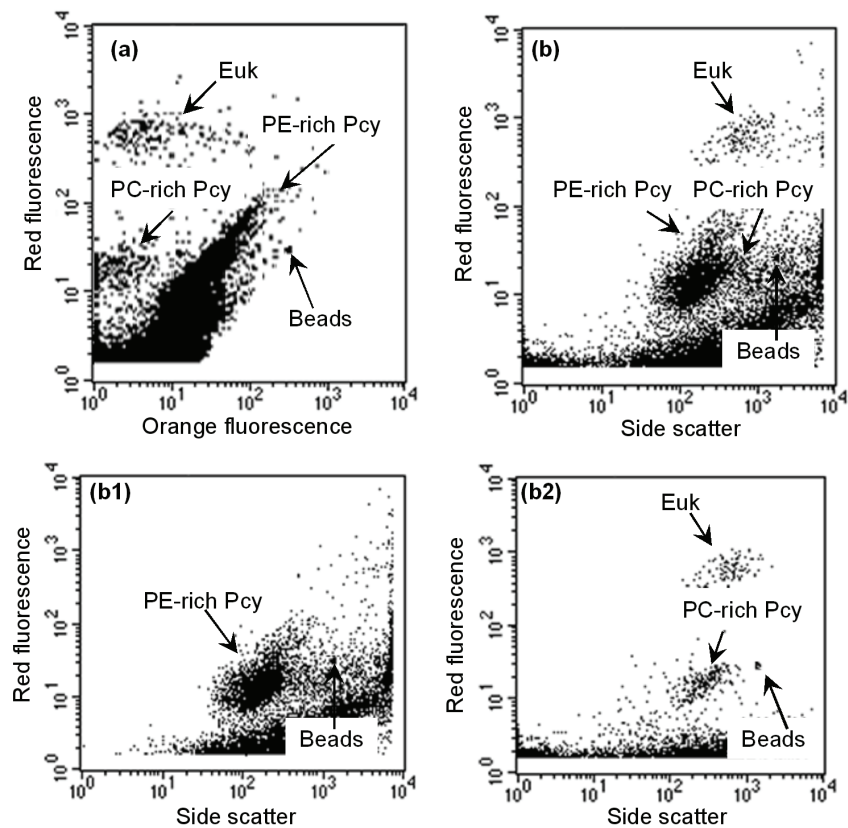

Fig. 3. Flow cytometric analysis of freshwater sample at station A2 in July in 2006. PC-rich Pcy, phycocyanin-rich picocyanobacteria; PE-rich Pcy, phycoerythrin-rich picocyanobacteria; Euk, picoeukaryotes; Beads, $1.002 \mu \mathrm{m}$ yellowish green fluorescent beads. Figure $\mathbf{b} 1$ and $\mathbf{b} 2$ were derived from figure $\mathbf{b}$.

The values of $\mathrm{NO}_{3}{ }^{-}$and $\mathrm{TN}$ in these investigated reservoirs did not show any significant differences; however, the values of $\mathrm{PO}_{4}{ }^{3-}$ and $\mathrm{TP}$ in Wujiangdu Reservoir were about $10^{2}$ and 10 times higher than that of other four reservoirs, respectively (Tab. 2), indicating that Wujiangdu Reservoir was hypereutrophic and the other four reservoirs were meso-eutrophic according to Vollenweider \& Kerekes (1982).

\subsection{Detection of Picocyanobacteria}

A group of red-fluorescing picocyanobacteria with lacking orange fluorescence (phycoerythrin) has been detected by flow cytometry in water samples collected in the investigated reservoirs. They could be discriminated from phycoerythrin-rich picocyanobacteria (PErich Pcy) by their lack of orange fluorescence (Fig. 3a) and from picoeukaryotes by their smaller side light scatter and much lower red (chlorophyll) fluorescence
(Fig. 3a, b, b2). These cells showed similar side light scatter to PE-rich Pcy (Fig. 3b, b1, b2), indicating both of them have similar cell size. They are probably a small phytoplankton with a phycocyanin-based light harvesting system which lacks phycoerythrin. They could be phycocyanin-rich picocyanobacteria (PC-rich Pcy). Further evidences are required to characterize these PC-rich Pcy (e.g., pigment characterization or molecular phylogenetics); however, they were not conducted in this study.

\subsection{Distributions of different picophytoplankton groups}

PE-rich Pcy, PC-rich Pcy and picoeukaryotes have been investigated in this study. The concentration of PC-rich Pcy was one order of magnitude higher than that of picoeukaryotes and one order of magnitude lower than that of PE-rich Pcy (Tab. 3). Picoeukaryotes showed comparable concentrations in different investi- 
gated months; however, the concentration of PC-rich Pcy in July was one order of magnitude higher than that in other three investigated months, and the concentration of PE-rich Pcy in January was one order of magnitude lower than that in other three investigated months (Tab. 3), indicating they had asynchronous responses to water temperature.

Tab. 3. Abundances of picophytoplankton in the reservoirs. Average $\pm \mathrm{SD}$; PC-rich Pcy, phycocyanin-rich picocyanobacteria; PE-rich Pcy, phycoerythrin-rich picocyanobacteria; Euk, picoeukaryotes.

\begin{tabular}{lccc}
\hline & $\begin{array}{c}\text { PC-rich Pcy } \\
\left(10^{3} \text { cells } \mathrm{mL}\right)\end{array}$ & $\begin{array}{c}\text { PE-rich Pcy } \\
\left(10^{3} \text { cells } \mathrm{mL}\right)\end{array}$ & $\begin{array}{c}\text { Euk } \\
\left(10^{2} \text { cells } \mathrm{mL}\right)\end{array}$ \\
\hline Month & & & \\
April & $3.2 \pm 3.6$ & $24.3 \pm 48.9$ & $4.3 \pm 4.7$ \\
July & $13.3 \pm 14.5$ & $19.1 \pm 16.9$ & $6.1 \pm 8.1$ \\
October & $4.2 \pm 4.8$ & $48.8 \pm 65.3$ & $2.4 \pm 2.8$ \\
January & $1.1 \pm 0.7$ & $8.9 \pm 6.8$ & $1.8 \pm 1.1$ \\
Reservoir & & & \\
Wujiangdu & $5.5 \pm 7.7$ & $5.2 \pm 8.9$ & $4.1 \pm 7.2$ \\
Dongfeng & $1.9 \pm 1.6$ & $41.1 \pm 63.3$ & $1.9 \pm 2.1$ \\
Hongjiadu & $2.4 \pm 2.1$ & $27.3 \pm 32.5$ & $1.8 \pm 1.9$ \\
Yinzidu & $2.8 \pm 3.2$ & $26.7 \pm 29.9$ & $4.1 \pm 3.4$ \\
Puding & $11.4 \pm 14.6$ & $38.4 \pm 55.0$ & $5.2 \pm 4.8$ \\
Total & $5.3 \pm 8.9$ & $25.5 \pm 44.4$ & $3.5 \pm 5.1$ \\
\hline
\end{tabular}

The concentrations of picoeukaryotes were similar among the investigated reservoirs (Fig. 4); however, PC-rich Pcy in Puding Reservoir (Fig. 5) and PE-rich Pcy in Wujiangdu Reservoir (Fig. 6) showed different concentrations from other four reservoirs (Tab. 3). This indicated they had different responses to trophic state of the investigated reservoirs.

The vertical distributions of three groups of picophytoplankton were similar in the investigated reservoirs and their abundances tended to decrease with depth (Fig. 4, 5, 6), which reflected the importance of light and temperature on their growths. The concentrations of the three autotrophs showed smaller vertical variations in January than that in other investigated months, probably due to no thermal stratification during winter. Generally, the picophytoplankton numbers of release water were obviously lower than those of surface water in these reservoirs when its thermal stratification was developed (Fig. 4, 5, 6).

\section{DISCUSSION}

\subsection{Relationships between picophytoplankton and hydrographic factors}

Each picophytoplankton group presented the lowest abundance in winter and showed a positive correlation between cell number and water temperature (Tab. 4), which indicated the influence of thermal stratification on their growths. However, the extent of temperature influencing PC-rich Pcy was more than that of PE-rich Pcy and picoeukaryotes, reflecting different responses of different picophytoplankton groups to temperature variations. Meanwhile, cell numbers of different picophytoplankton groups were all negatively correlated to depth. This may reflect the importance of light quality on their growth (e.g., Voros et al. 1998).

Nutrient supply is an important factor affecting the picophytoplankton distributions (Stockner \& Shortreed 1994; Vrede et al. 1999). PE-rich Pcy exhibited a negative correlation with $\mathrm{PO}_{4}{ }^{3-}$ in autumn in these reservoirs (Tab. 4), reflecting that high phosphate concentration decreases picocyanobacterial growth rates (e.g., Schallenberg \& Burns 2001). However, high phosphate can not constrain the PE-rich Pcy growth at higher water temperature $\left(23.1 \pm 4.7^{\circ} \mathrm{C}\right)$ in summer, suggesting that there are multi-factors in controlling PE-rich Pcy abundance. Other factors such as grazing by ciliates (Chang et al. 2003) or other microzooplankton, viral infections and co-sedimentation with organic particles (Fuhrman 1999; Waite et al. 2000) may also affect the picophytoplankton distributions; however, they were not tested in this study.

Tab. 4. Relationships between picophytoplankton and temperature $(\mathrm{n}=226)$, depth $(\mathrm{n}=226)$, and $\mathrm{PO}_{4}{ }^{3-}(n=60)$, respectively, in terms of the results of Pearson's correlation coefficient. **, Correlation is significant at the 0.01 level (2-tailed); *, Correlation is significant at the 0.05 level (2tailed).

\begin{tabular}{lccl}
\hline & Temperature & Depth & $\mathrm{PO}_{4}{ }^{3-}$ \\
\hline PC-rich Pcy & $.549^{* *}$ & $-.294^{* *}$ & -.015 \\
PE-rich Pcy & $.263^{* *}$ & $-.325^{* *}$ & $-.256^{*}$ \\
Picoeukaryotes & $.414^{* *}$ & $-.298^{* *}$ & -.132 \\
\hline
\end{tabular}

\subsection{Variations of different picophytoplankton groups in the cascade reservoirs}

Variations in abundances of picophytoplankton reveal distinct abilities of different picophytoplankton groups to cope with different environmental factors (e.g., water temperature, light, and trophic state). PErich Pcy, PC-rich Pcy and picoeukaryotes presented different ratios of the cell numbers from each other (Fig. 7) due to different trophic state in these cascade reservoirs.

Damming on river can cause considerable reductions in nutrient loads owing to the removal of these nutrients in reservoir sediments. However, this removal might be overcompensated by anthropogenic trophic inputs downstream of the reservoir. This is the case of Wujiangdu Reservoir. Its high phosphorus concentration is due to fishery and excess phosphorus input by the Xifeng River, a southern tributary of the Wujiang River. For the cascade reservoirs, upriver reservoir receives more nutrient than downriver reservoir. This is the case of Puding Reservoir that shows a higher trophic state than Dongfeng Reservoir although both are impounded in 1989. Puding Reservoir is still more trophic than Hongjiadu Reservoir because of its longer running time although they are upriver reservoirs. The change of picophytoplankton community structure reflects these situations very well. 


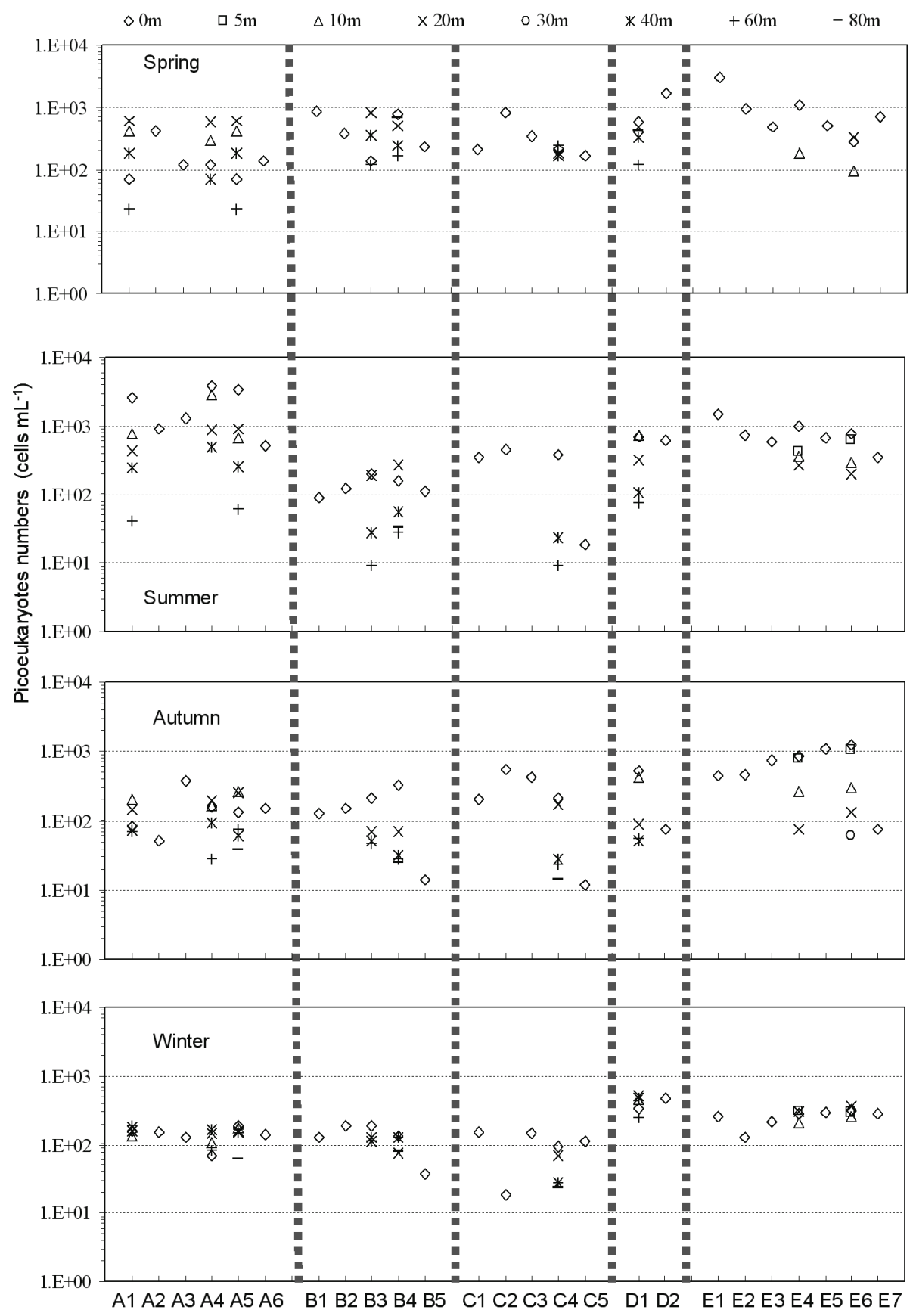

Fig. 4. Profile of picoeukaryotes in the investigated reservoirs. 


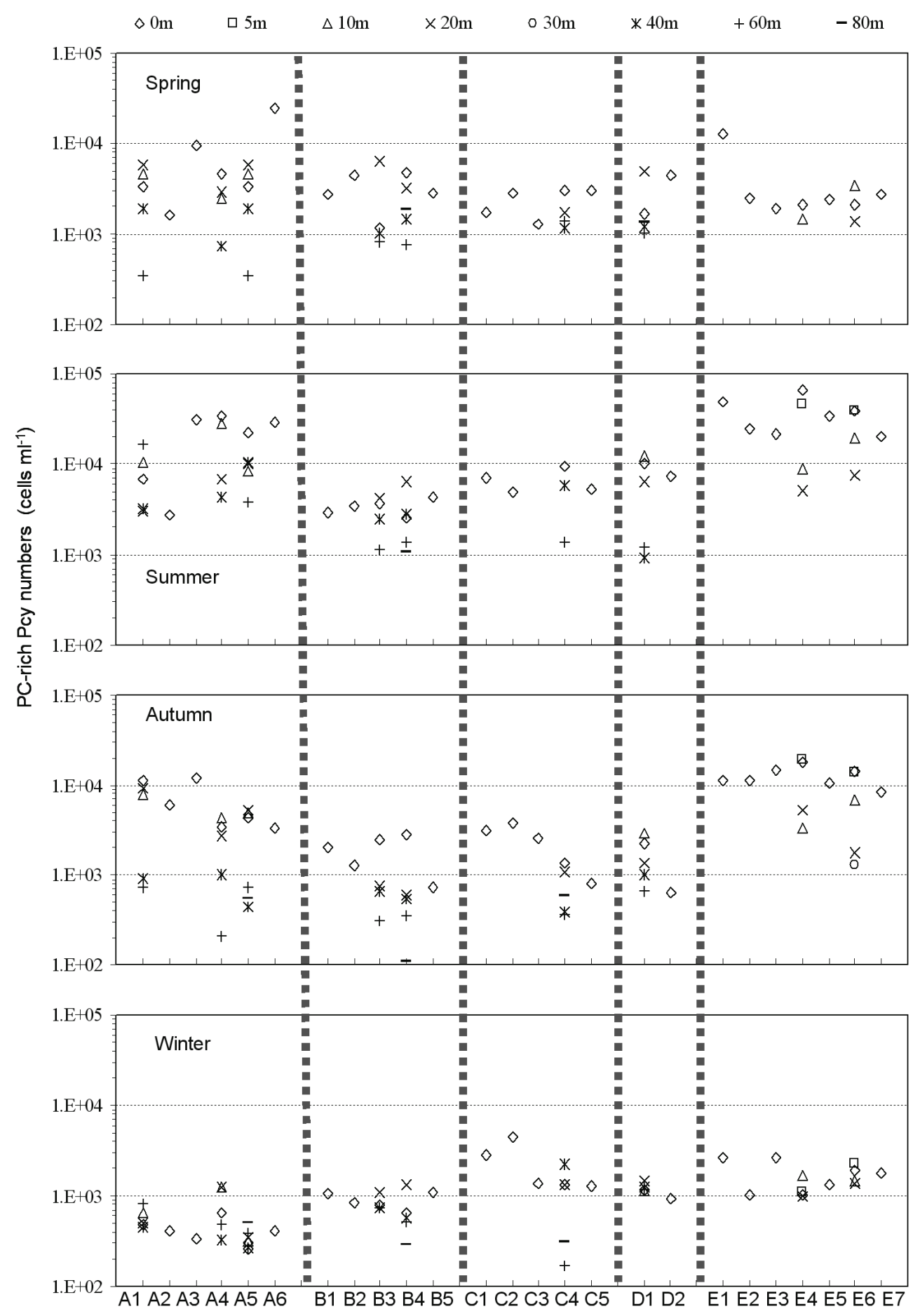

Fig. 5. Profile of phycocyanin-rich picocyanobacteria (PC-rich Pcy) in the investigated reservoirs. 


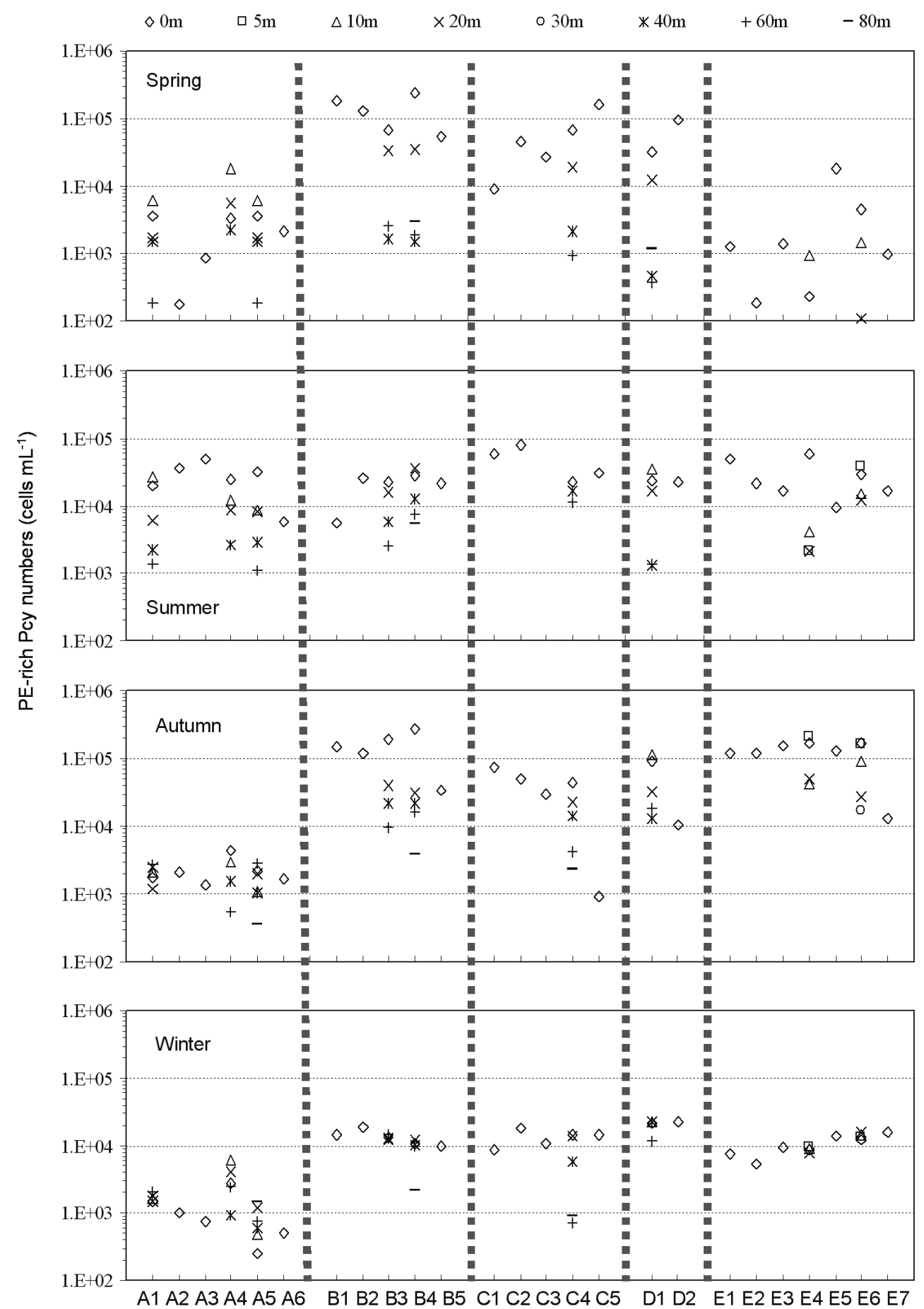

Fig. 6. Profile of phycoerythrin-rich picocyanobacteria (PE-rich Pcy) in the investigated reservoirs. 

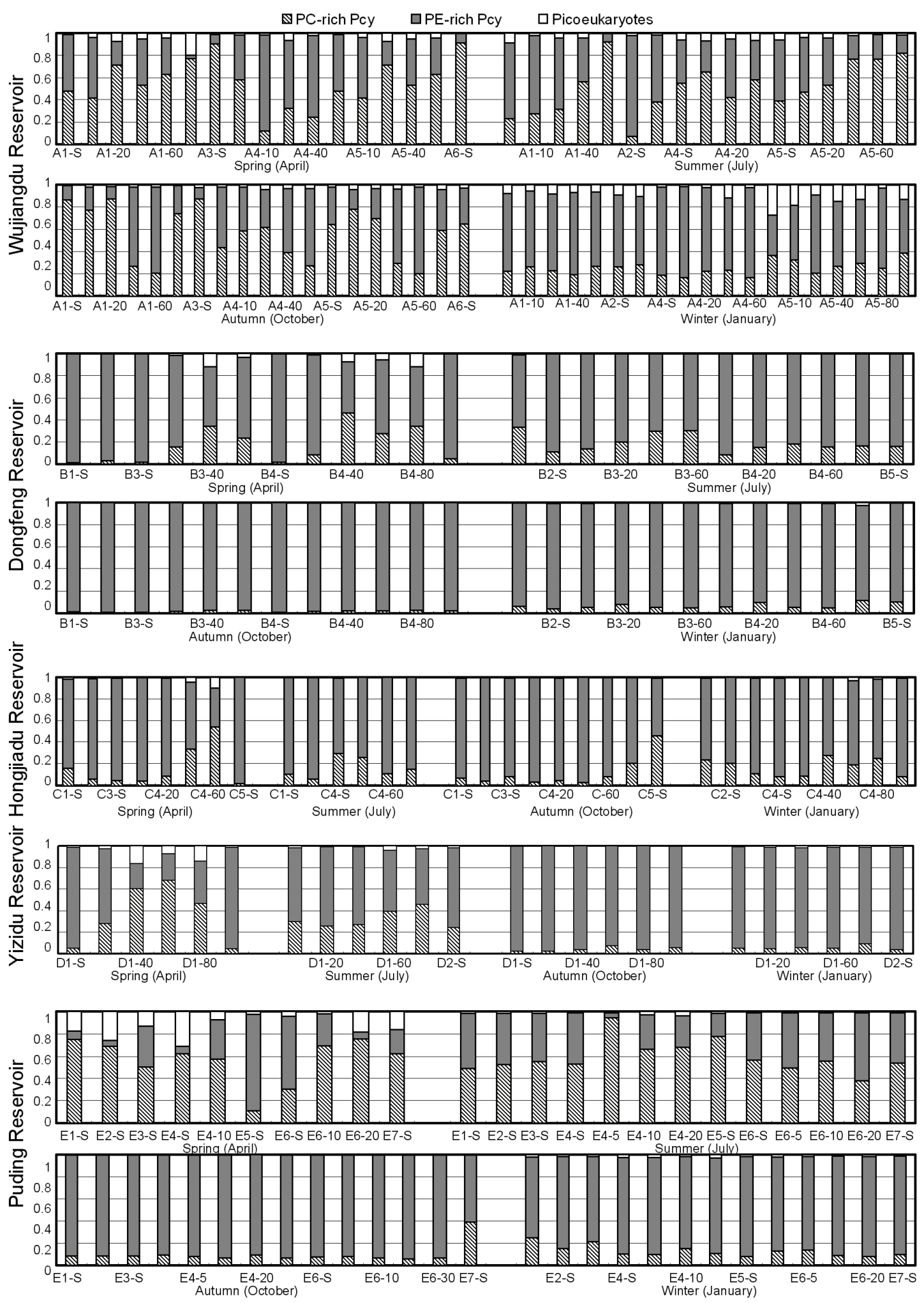

Fig. 7. Picophytoplankton community structure in the investigated reservoirs. PC-rich Pcy, phycocyanin-rich picocyanobacteria; PErich Pcy, phycoerythrin-rich picocyanobacteria. A1-S is the water sample of A1 at surface; A1-20 is the water sample of A1 at the depth of 20 meters. 
With eutrophication, the abundance of PE-rich Pcy decreased and that of PC-rich Pcy increased (Fig. 7). This is in agreement with the model presented by Voros et al. (1998) and with the results in different lakes (Callieri 1996). So, picophytoplankton community structure transformed from dominant PE-rich Pcy to dominant PE-rich Pcy and PC-rich Pcy (e.g., in Wujiangdu Reservoir). Picoeukaryotes was a minor contribution to autotrophic picoplankton $(<5 \%)$ (Weisse 1993; Padisak et al. 1997; Callieri 2007); and in this study the increase of picoeukaryotes with eutrophication (e.g., $>10 \%$ in Wujiangdu Reservoir) was found. The seasonal variation of picophytoplankton community structure also reflected different responses of autotrophic picoplankton to temperature. The investigation about autumn phytoplankton composition showed that Margalef diversity index and Shannon-Weiner index can not discern trophic state of these five reservoirs (Wang et al. 2008); however, the change of picophytoplankton community structure can, suggesting they are excellent indicators for the change of trophic state.

\section{CONCLUSIONS}

Besides picoeukaryotes, two groups of picocyanobacteria have also been detected by flow cytometry. One is a phycoerythrin-rich picocyanobacteria (PE-rich Pcy), the other is a red-fluorescing cells with lacking orange fluorescence and could be a phycocyanin-rich picocyanobacteria (PC-rich Pcy). In 2006 and 2007, the average numbers of PC-rich Pcy, PE-rich Pcy and picoeukaryotes in the cascade reservoirs along the Wujiang River were $10^{3}, 10^{4}$ and $10^{2}$ cells $\mathrm{mL}^{-1}$, respectively. A positive correlation with water temperature and a negative correlation with depth were found for each group. PE-rich Pcy was the dominant population among picophytoplankton groups but showed a reduction with eutrophication. Picophytoplankton community structure presented a change in these cascade reservoirs because of their different trophic states and showed a seasonal variation in response to the different water temperature, suggesting they are excellent indicators for environmental change.

\section{ACKNOWLEDGMENTS}

This study was financially supported by National Natural Science Foundation of China (Grant Nos. 90610037, 40603006 and 40721002) and by the Foundation of Chinese Academy of Sciences (International Partnership Project). We are grateful to Dr. C. Callieri for valuable comments and suggestions on this manuscript, and to the assistance of Ms. Lihua Zhang for sample determination.

\section{REFERENCES}

Agawin, N.S.R., C.M. Duarte \& S. Agusti. 2000. Nutrient and temperature control of the contribution of picoplankton to phytoplankton biomass and production. Limnol. Oceanogr., 45: 591-600.

Bell, T. \& J. Kalff. 2001. The contribution of picophytoplankton in marine and freshwater systems of different trophic status and depth. Limnol. Oceanogr., 46: 12431248.

Becker, A., A. Meister \& C. Wilhelm. 2002. Flow cytometric discrimination of various phycobilin-containing phytoplankton groups in a hypertrophic reservoir. Cytometry, 48: 45-57.

Callieri, C. 1996. Extinction coefficient of red, green and blue light and its influence on picocyanobacterial types in lakes at different trophic levels. Mem. Ist. ital. Idrobiol., 54: 135-142.

Callieri, C. \& J.G. Stockner. 2002. Freshwater autotrophic picoplankton: a review. J. Limnol., 61: 1-14.

Callieri, C. 2007. Picophytoplankton in freshwater ecosystems: the importance of small-sized phototrophs. Freshwater Reviews, 1: 1-28.

Chang, J., K.H. Lin, K.M. Chen, G.C. Gong \& K.P. Chiang. 2003. Synechococcus growth and mortality rates in the East China Sea: range of variations and correlation with environmental factors. Deep-Sea Res. II, 50: 1265-1278.

Collier, J.L. 2000. Flow cytometry and the single cell in phycology. J. Phycol., 36: 628-644.

Fuhrman, J.A. 1999. Marine viruses and their biogeochemical and ecological effects. Nature, 399: 541-548.

Glazer, A. N. 1982. Phycobilisomes: structures and dynamics. Ann. Rev. Microbiol., 36: 173-198.

Han, G. \& C.Q. Liu. 2004. Water geochemistry controlled by carbonate dissolution: A study of the river waters draining karst-dominated terrain, Guizhou Province, China. Chem. Geol., 204: 1-21.

Humborg, C., V. Ittekkot, A. Cociasu \& B.V. Bodungen. 1997. Effect of Danube river dam on Black Sea biogeochemistry and ecosystem structure. Nature, 386:385-388.

Ittekkot, V. 1988. Global trends in the nature of organic matter in river suspensions. Nature, 332: 436-438.

Meybeck, M. 1982. Carbon, nitrogen, and phosphorus transport by world rivers. Amer. J. Sci., 282: 401-450.

Pan, L.A., L.H. Zhang, J. Zhang, J.M. Gasol \& M. Chao. 2005. On-board flow cytometric observation of picoplankton community structure in the East China Sea during the fall of different years. FEMS Micro. Ecol., 52:243-253.

Padisak, J., L. Krienitz, R. Koschel \& J. Nedoma. 1997. Deeplayer autotrophic picoplankton maximum in the oligotrophic Lake Stechlin, Germany: origin, activity, development and erosion. Eur. J. Phycol., 32: 403-416.

Pick, F.R. 1991. The abundance and composition of freshwater picocyanobacteria in relation to light penetration. Limnol. Oceanogr., 36: 1457-1462.

Schallenberg, M. \& C.W. Burns. 2001. Tests of autotrophic picoplankton as early indicators of nutrient enrichment in an ultra-oligotrophic lake. Freshwat. Biol., 46: 27-37.

Sieburth, J.M., V. Smetacek \& J. Lenz. 1978. Pelagic ecosystem structure: heterotrophic compartments of the plankton and their relationship to plankton size fractions. Limnol. Oceanogr., 23: 1256-1263.

Stockner, J.G. \& K.S. Shortreed. 1994. Autotrophic picoplankton community dynamics in a pre-alpine lake in British Columbia, Canada. Hydrobiologia, 274: 133-142.

Stockner, J.G. 1988. Phototrophic picoplankton: an overview from marine and freshwater ecosystems. Limnol. Oceanogr., 33: 765-775.

Stockner, J.G., C. Callieri \& G. Cronberg. 2000. Picoplankton and other non-bloom forming cyanobacteria in lakes. In: Whitton, B. and M. Potts (Eds), Ecology of Cyanobacteria: Their Diversity in Time and Space. Kluwer Academic Publishers: 195-231. 
Szelag-Wasielewska, E. 1997. Picoplankton and other size groups of phytoplankton in various shallow lakes. Hydrobiologia, 342/343: 79-85.

Vrede, K., T. Vrede, A. Isaksson \& A. Karlsson. 1999. Effects of nutrients (phosphorous, nitrogen, and carbon) and zooplankton on bacterioplankton and phytoplankton-a seasonal study. Limnol. Oceanogr., 44: 1616-1624.

Vollenweider, R. A. \& J. Kerekes. 1982. Eutrophication of waters: monitoring assessment and control. Organization for Economic Co-Operation and Development (OECD), Paris: $156 \mathrm{pp}$.

Voros, L., C. Callieri, K.V. Balogh \& R. Bertoni. 1998. Freshwater picocyanobacteria along a trophic gradient and light quality range. Hydrobiologia, 369/370: 117-125.

Wakabayashi, T. \& S. Ichise. 2004. Seasonal variation of phototrophic picoplankton in Lake Biwa (1994-1998). Hydrobiologia, 528: 1-16.

Received: October 2008

Accepted: December 2008
Waite, A.M., K.A. Safi, J.A. Hall \& S.D. Nodder. 2000. Mass sedimentation of picoplankton embedded in organic aggregates. Limnol. Oceanogr., 45: 87-97.

Wang, B., C.Q. Liu, F. Wang, Y. Yu \& L.H. Zhang. 2008. The distributions of autumn picoplankton in relation to environmental factors in the reservoirs along the Wujiang River in Guizhou Province, SW China. Hydrobiologia, 598: 35-45.

Wehr, J.D. 1993. Effects of experimental manipulation of light and phosphorus supply on competition among picoplankton and nanoplankton in an oligotrophic lake. Can. J. Fish. Aquat. Sci., 50: 936-945.

Weisse, T. 1993. Dynamics of autotrophic picoplankton in marine and freshwater ecosystems. Adv. Microbiol. Ecosyst., 13: 327-370.

Wetzel, R.G. 2001. Limnology: Lake and river ecosystems. 3rd Ed. Academic Press. San Diego: 1006 pp. 